\title{
ИСТОРИЯ КАК НАСТАВНИЦА: ИЗУЧЕНИЕ С. П. КОЛОШИНЫМ ИСТОРИЧЕСКИХ ЭКСПОЗИЦИЙ ЕВРОПЕЙСКИХ МУЗЕЕВ
}

\author{
Н. А. Бойко \\ (Московский гуманитарный университет)
}

Аннотация: В статье представлен аспект творчества известного московского публициста, писателя и издателя середины ХІХ в. С. П. Колошина, связанный с деятельностью европейских музеев. Анализируются особенности его восприятия музеев, которые он посетил и ознакомился с их историческими экспозициями.

Ключевые слова: С. П. Колошин; история музеев; европейские музеи; музееведение; Рим

\section{HISTORY AS A MENTOR: S.P. KOLOSHIN'S STUDY OF HISTORICAL EXHIBITIONS IN EUROPEAN MUSEUMS}

\author{
N. A. Boyko \\ (Moscow University for the Humanities)
}

Abstract: In this article we discuss a less-known aspect of the creative work of the a mid-19th century Moscow journalist, writer and publisher Serguei P. Koloshin - his interest in European museums. We take a look at his specific perception of the museums he visited and of their historical sections and their exhibits.

Keywords: S. P. Koloshin; history of museums; European museums; museology; Rome

Сергей Павлович Колошин - известный московский публицист, писатель и издатель 1850-1860-х гг. В середине 60-х годов XIX века он впервые посетил Западную Европу. Как и многие образованные дворяне, впервые приезжавшие в Европу, он стремился непременно познакомиться с новой, неизвестной до этого культурой. Колошин всегда считал важным для просвещения изучение истории. Поэтому, приехав в Европу, он сразу же отправился в музеи. Свои многочисленные впечатления от Европы по приезду в Россию русский литератор изложил в книге «Европа и европейцы. Зигзаги и арабески русского туриста», опубликованной в Москве в 1866 г. (Колошин, 1866а). 
Изучение литературной, просветительной, публицистической, издательской деятельности С. П. Колошина (в качестве предмета исследования) открывает новые грани сравнительно нового направления в исторической науке - культурно-социальной истории. Творческое наследие Колошина как неординарное явление в общественной жизни практически не изучено (см.: Бойко, 2014abcd; 2015). Его деятельность и творчество известно немногим специалистам (см.: Захаров, 2013).

Личность Колошина как объект исторического исследования позволяет осмыслить его мировоззренческие установки «просвещенного наблюдателя» (как он сам себя позиционировал) - его нельзя отнести ни к либералам, ни к консерваторам, ни к славянофилам, ни к западникам. Взгляд реалиста на противоречия александровской модернизации в России, дополненный внимательным изучением жизни и культуры западноевропейского общества, представляют для исторической науки значимые материалы для понимания общественных процессов и изменений середины - второй половины XIX в.

С. П. Колошин посещал театры, музеи, массовые мероприятия в Дрездене, Берлине, Вене, Праге, Венеции, Милане. Особое отношение у него проявилось к музеям и картинным галереям. Он с тончайшими подробностями описывал в книге каждую увиденную картину или музейную фигуру, отчего чтение книги становилось нелегким занятием, особенно если читатель не видел изображения.

Колошин осознавал бессмысленность описания музеев и выставок в книжном издании. Он понимал, что беглый перечень не составит понятия о музеях, но объяснял причину такого описания так: «Мне только хотелось показать, какую вечно открытую энциклопедически-историческую иллюстрацию имеют здесь ученый и художник» (Колошин, 1866а: 34). Это было привлечением внимания читателей, своего рода путеводитель. Таким образом Колошин советовал, что стоило посмотреть, приезжая в Европу. В целом книга получилась интересной и познавательной. На обложке написано - «выпуск 1», следовательно, предполагался второй выпуск, но, к сожалению, второго выпуска этой книги автор подготовить не успел. Часть колошинских заметок были опубликованы в газетах и журналах, а также в письмах к известному историку М. П. Погодину.

Колошин утверждал, что историку, желающему серьезно преподавать историю, следует знакомиться с памятниками той или иной эпохи в местах их существования, а не по описаниям и рисункам, которые никогда не заменят живого восприятия. Еще сложнее, по словам Колошина, определить посещение мест, достойных внимания историка. Понятия о достопримечательном относительны. Колошин процитировал слова петербургского историка профессора И. П. Шульгина, который говорил, что 
история - это «описание достопримечательных происшествий рода человеческого» (там же: 32). Колошин добавил: «но что достопримечательно для ученого, на то плевать хотел сапожник! Что достопримечательно для государственного мужа, то нередко презирает философ» (там же). Он оговаривался, что все культурные заведения обойти невозможно, сам он выбрал по своему вкусу «достойное для наблюдения и поучительное для всех» (там же).

Противоречивые ощущения испытал Колошин, войдя в Оружейную палату в Дрездене. Конечно, она была бы интересной для любителей оружия, но Колошин вышел оттуда угнетенным, потому, что было тяжело бродить среди массы человекоубийственных орудий, ходить перед артефактами изобретений, направленных против человеческой жизни. Колошин почувствовал обиду за глупость и бесстыдство человеческого рода. Увидев огромное количество достояний рыцарства, столько превозносимого и поэтизируемого, он признавался, что рыцарство никогда не вызывало в нем такого отвращения, как при выходе из дрезденской Оружейной палаты.

В музее Потсдама Колошин удивлялся: что особенного мог нахо-дить Вольтер в прусском короле Фридрихе Великом, а Гумбольдт во ФридрихеВильгельме IV? Он задумался о том, не грешит ли слишком часто беспристрастная история, когда в оценках великих людей обычно руководствуется отзывами современников, которые далеко не всегда имели возможность высказывать искреннее мнение, а это могло искажать истинную картину прошлого. Колошин считал, что при изучении исторического прошлого это необходимо учитывать, поэтому надо прорабатывать эти вопросы «в эпоху, которая, не знаю, стремится ли к истине, но хвалится, по крайней мере, что рвется к ней всеми своими сердечными биениями» (там же: 45 ).

С. П. Колошин всегда подчеркивал, что он не принадлежал ни к какой партии, он всегда старался быть независимым от чьего-то мнения. Русский писатель и публицист не хотел писать в угоду публике - он желал верить в то, что писал, быть искренним для публики, оставить свои пристрастия в стороне и относиться объективно и беспристрастно к описываемым явлениям. Таких же и даже еще более жестких требований, по его мнению, должна придерживаться историческая наука. Колошин понимал, что многие современники необъективны. Поэтому настаивал, что они должны иметь внутреннюю порядочность, чтобы писать правду о своем времени, не оглядываясь на чужое мнение и авторитеты. Но, к сожалению, далеко не все так поступали.

Колошин стремился подать собственный пример, как должен поступать публичный человек, к которому могли прислушаться как современники, так и будущие потомки. Даже в своей повседневной жизни человек 
зависим от чужих мнений, но он не замечает этого. Колошин приводил примеры из своей жизни: когда ему что-то дарили (книгу, лошадь и пр.), нередко хвалимое не соответствовало его требованиям. Когда его знакомили с красивой и умной женщиной, она оказывалась совсем не такой, как ему представляли, поэтому, констатировал он, так и не нашел себе жены. После многих горьких опытов и бесчисленных разочарований он признал за собой, как он выразился, ребяческую манию веры в абсолют. Но он не собирался отступаться от своих принципов. Например, решил для себя не смотреть ничего прославленного и обсуждаемого, и начинать читать новую книгу только тогда, когда все замолчат о ней.

По поводу исторических событий Колошин предостерегал о недопустимости недостоверной трактовки. По его мнению, все знали, что Людовик XIV - герой прошлого, великий деятель, а Людовик-Наполеон современный персонаж - почему-то тоже считался великим, хотя стал кровавым. Отсюда скептическое отношение Колошина к истории. Путешественники, описывавшие Европу, издавна приняли за правило смотреть на большинство достопримечательностей с однажды определенной точки зрения. Таким образом составилась цепь рапсодий, героиада (по примеру: Илиада. - Н. Б.) достопримечательностей, мало-помалу дополнявшаяся, потом она утверждалась в учебниках. Готовясь посетить Неаполитанский залив, собор святого Петра, Колошин готовился к чуду, восхищению, а увидел претензию произвести чудо. По его мнению, многие детали собора святого Петра нарушали эстетическое впечатление. После двух-трех таких разочарований, по признанию Колошина, у него появилось недоверие ко всему (Колошин, 1866b: 212-213).

Вообще обычно все путешествия и рассказы об Италии полны поэтических восторгов страной и людьми. Колошин писал, что он не привык вдохновляться чужими впечатлениями и общепризнанными авторитетами, поэтому описывал свои собственные впечатления, стремясь дать всему увиденному свою собственную оценку, не зависевшую от других впечатлений и мнений. Он считал, что публицисты едва ли не единственные в своем роде, имеющие способность здраво и объективно подходить к обсуждению культурной и общественной жизни. Пообщавшись в Италии с писателем А. Дюма-сыном, Колошин узнал, что тот плохо относился к неаполитанцам. Колошин сразу же пояснил, что Дюма - романист, к тому же поэт, и его миросозерцание не может быть меркой для публициста. По наблюдениям Сергея Павловича, гипербола и красное слово у Дюма родятся сами, как у поэта рифмы, он и сам не чувствует, как уклоняется от действительности, но искренне верит в свои произвольные представления. Колошин не отрицал творчество писателей и поэтов, однако считал, что у них другое отношение к действительности, иные критерии оценки реальности. 
С. П. Колошин видел в музеях не только элемент прошлого - он сравнивал ее с настоящей, современной ему жизнью. Увидев в неаполитанском музее Борбонико рыцарей с копьями, кольчугами и другими вооружениями, Колошин удивлялся: какой современный человек теперь выдержит все это на себе? Вывод получился не в пользу современного человека. Где же эти нынешние Голиафы? Колошину сразу подумалось о физическом измельчении и ослаблении человеческого рода, силы человечества опасно вырождались. Поэтому он считал, что в эпоху физического движения вперед в области естественных наук, человек должен помнить и о себе, необходимо развивать такую науку, как антропология. Эта проблема, по мнению Колошина, заслуживала серьезного обсуждения. Она остается актуальной и сегодня (см.: Тихомирова, 2012).

Больше всего Колошина взволновала судьба Рима. По его наблюдениям, в кругу европейских благоустроенных центров Рим выглядел как город-чердак, город-погреб, в котором много столетий свалена бездна драгоценностей, предоставленных на произвол судьбы, шло медленное тление города. И здесь Колошин имел в виду тление не только культурных ценностей. В своих неопубликованных письмах он писал об «испорченном состоянии» самого города, признавался, что у него осталось тяжелое впечатление о Риме. Для него Рим был пыткой, он видел в нем «отсутствие жизни в том смысле как разуметь ее для большого города в наше время» (Научно-исследовательский отдел рукописей Российской государственной библиотеки - НИОР РГБ. Ф. 231, разд. III. К. 6. Д. 28). При прикосновении к чему-либо из прошлого, констатировал Колошин, одно заброшено, другое изувечено, третье забыто.

С целью восстановления города Колошин внес собственное предложение. Суть его заключается в следующем. Рим надо обратить в высшее место образования эстетического и гуманистического, он должен иметь мировое значение, а для мировой культуры принадлежность к какому-либо государству не важна. Поэтому надо, чтобы европейские державы сделали общеполезное, неполитическое дело, а именно: восстановили розыск древностей, учредили две академии (одна для пла-стических искусств, другая для истории, древностей и филологии). Эти учреждения были бы открыты для всех желающих и бесплатно. Колошин писал: «Распространение высшего гуманистического и эстетического образования есть ведь ничто иное как разработка и изощрение моральных и умственных сил человечества, стало быть, успех производительности и, следовательно, удобрение материально полезное; хороший и полный курс философской истории, какой имеются лишь образчики или отрывки, был бы благодатью для всякой че-ловеческой единицы для народов и правительств; история бы действительно вошла на ступень всемирной наставницы» (Колошин, 1866а: 213). Легче всего, по мнению Колошина, все это сделать в Риме, к 
тому же европейские правительства могли бы создать в Риме высшую школу в Европе, куда бы стекались все лучшие умы, лучшие дарования, несмотря на все межгосударственные разногласия, и общение всех национальностей стало бы благотворным для всех государств и народов.

Колошин был уверен, что у римлян нужно учиться строить, но нужно, прежде всего, восстановить Рим в совершенстве, превратить его из брошенного склада достопримечательностей во всемирный музей. Колошин выбрал для этой цели Рим неслучайно. С Римом связан образ великого города, он уникален своей историей, это символ гражданственности и правопорядка. И Рим таковым являлся не только для него, а для всего человечества. Нельзя не согласиться с мнением, что «образ Рима, с одной стороны, уникален, но в то же время чрезвычайно популярен. Его стремятся использовать не только отдельные города, но и целые государства, что отчасти привело к тому, что Рим во многих культурах признается столицей мира либо вместилищем целого мира, соединением традиций и всепоглощающим городом» (Агишева, 2008: 112-113). Именно поэтому Колошину печально было видеть упадочное состояние этого города. Правда, в своей истории Рим не был таким уж идеальным, этот мифологический образ был создан уже последующими поколениями. Однако для европейского мира он всегда виделся именно образцом культуры и образования, поэтому предложение Колошина было вполне достойно внимания со стороны европейских правительств.

Определение истории как «всемирной наставницы», сформированное в образно-чувственном восприятии русского литератора и публициста С. П. Колошина после посещения и изучения исторических экспозиций в европейских музеях, получило научное обоснование в 1880-е гг. в трудах его современника - выдающегося теоретика истории Н.И. Кареева. Историко-культурный подход, заинтересовавший и вдохновивший Колошина, получил теоретические и методологические основания в историологии Кареева. Представитель русской исторической школы констатировал, что лишь в XIX в. история превратилась из исторического искусства в историческую науку. До этого была история прагматическая - история событий. Культурная история есть создание XIX в. - история быта, история форм жизни и их изменений.

В истории интеллектуальной мысли одним из важнейших качественных явлений Кареев признавал интеллектуальный переворот середины XIX в. (отметим, что именно в этот период С. П. Колошин заинтересовался европейскими музеями): в это время происходило вытеснение научными точками зрения и методами мышления господствовавших ранее мистических, метафизических и романтических идей не только в общем миросозерцании, но и в понимании общественных задач и способов их решения. Это была замена прежнего идеаллизма реалистической тенден- 
цией как в теоретической, так и в практической мысли, характеризующаяся стремлением к точному знанию, основанному на опыте и наблюдении, вместо умственных построений в виде отвлеченных соображений либо деятельности безудержного воображения. Хронологически линия интеллектуального водораздела между идеализмом и реализмом проходила через середину XIX века. Представляется, что писатель и публицист Колошин выступал в качестве представителя направления реализма.

По оценке Н. И. Кареева, наука, литература и искусство в очень многих случаях стоят слишком далеко от проблем текущего дня и имеют свою особую эволюцию, на которой или совсем не отражается, или отражается в весьма слабой степени эволюция общественных отношений. При этом в данных областях основную роль играют очень часто специальные темы: научные открытия и проблемы, методы науки, вопросы стиля, техники и т. п. в музыке или в изобразительном искусстве и пр. В развитии науки, литературы и искусства историка может интересовать не их специфическая, а общекультурная и общественная сторона. Там, где было уместно и важно, например, в истории XIX в., Кареев использовал факты из истории естествознания, поскольку оно влияло на общее миросозерцание (например, теория Дарвина), материалы о литературных явлениях, поскольку последние имели значение для своего времени (например, романтизм, социальный роман, натурализм), факты из истории социальных наук.

В историологии Кареева важным звеном является деление исторического процесса на прагматическую историю (или прагматику) и культурную историю (или культуру). То, что делают люди - называется прагматикой, как они это делают - культурой. С одной стороны, актуально что, почему и для чего делали в прошлом люди, с другой чрезвычайно важно, как жили, думали, работали те же люди, причем это как значит в иных случаях в каких условиях, а в иных - в каких формах. Это задачи истории прагматической в первом случае и культурной - во втором. На общей основе синтетического понимания исторического процесса как взаимодействия прагматики и культуры, сводящегося в последнем анализе к разнообразным взаимодействиям между отдельными людьми, могут, в конце концов, получить полное разрешение все наиболее существенные проблемы исторического процесса (см.: Васильев, 2006, 2010ab, 2011, 2012ab).

\section{СПИСОК ЛИТЕРАТУРЫ}

Агишева, О. В. (2008) Образ города в российском политическом пространстве // Вестник Томского государственного университета. Философия. Социология. Политология. № 2. С. 99-115.

Бойко, Н. А. (2014а) С. П. Колошин как очевидец объединения Италии: актуальные исторические уроки для России и Европы // Полиграфист. № 
3. C. $89-96$.

Бойко, Н. А. (2014b) С.П. Колошин: между славянофилами и западниками // Власть. № 6. С. 76-80.

Бойко, Н. А. (2014c) С.П. Колошин: предчувствие реформ // Власть. №8. C. 127-130.

Бойко, Н.А. (2014d) Трансформация общественной и издательской деятельности С.П.Колошина в 1863 г.: польский вопрос [Электронный ресурс] // Информационный гуманитарный портал «Знание. Понимание. Умение».№ 6 (ноябрь - декабрь).URL:http://www.zpu-journal.ru/e-zpu/2014/6/ Boyko_Koloshin-Polish-Question/ (дата обращения: 21.12.2014).

Бойко, Н. А. (2015) «Просвещенный наблюдатель»: общественная деятельность С. П. Колошина в условиях начала российских реформ 1860-х гг. // Научные труды Московского гуманитарного университета. №1. C.49-57.

Васильев, Ю. А. (2006) «Кризис истории» - кризис понимания истории // Знание. Понимание. Умение. № 1. С. 35-40.

Васильев, Ю. А. (2010а) Феномен «Ecole Russe»: теория истории Н.И.Кареева (начало) // Знание. Понимание. Умение. № 2. С. 124-128.

Васильев, Ю. А. (2010b) Феномен «Ecole Russe»: теория истории Н.И.Кареева (окончание) // Знание. Понимание. Умение. № 3. С. 121-134.

Васильев, Ю. А. (2011) Феномен «Ecole Russe»: критика Н. И. Кареева // Знание. Понимание. Умение. № 3. С. 121-127.

Васильев, Ю. А. (2012а) Взгляд на эпометаморфоз сквозь призму всемирно-исторической точки зрения // Век глобализации. № 1. С. 46-57.

Васильев, Ю.А. (2012b) Феномен «Ecole russe»: историология Н. И. Кареева // Знание. Понимание. Умение. № 1. С. 72-81.

Захаров, В.Н. (2013) Неопубликованный автограф Достоевского: Ф.М.Достоевский и С.П. Колошин // Ученые записки Петрозаводского государственного университета. № 7. С. 58-61.

Колошин, С. П. (1866а) Европа и европейцы. Зигзаги и арабески русского туриста. Вып. 1. М. : Типография Катков и К․ 218 с.

Колошин, С. П. (1866b) Три дня на итальянских озерах // Утро: литературный сборник / под ред. М. П. Погодина. М. : В типографиях Бахметева на Малой Дмитровке № 14, Бочарова, Степанова и Миллера. 470 с.

Тихомирова, Л. Ю. (2012) История науки и техники. Конспект лекций. М. : Изд-во Москов. гуманит. ун-та. 224 с.

Бойко Надежда Анатольевна - аспирант кафедры истории Московского гуманитарного университета. Адрес: 111395, Россия, г. Москва, ул. Юности, д. 5, корп. 3. Тел.: +7 (499) 374-55-81. Эл. адрес: historymosgy@ mail.ru. Научный руководитель - д-р ист. н., проф. Ю. А. Васильев. 
Boyko Nadezhda Anatolievna, Postgraduate student, Department of History, Moscow University for the Humanities. Postal address: 5 Bldg. 3 Yunosti St., 111395, Moscow, Russian Federation. Tel.: +7 (499) 374-55-81. E-mail: historymosgy@mail.ru. Research adviser - Yuri A. Vasiliev, Doctor of History, Professor. 